\title{
Challenges and Opportunities of Business Process Outsourcing in India
}

By: Anju Mehta, Achilles Armenakis, Nikhil Mehta, and Feruzan Irani

Mehta, A., Armenakis, A., Mehta, N. and Irani, F. (2006). Challenges and Opportunities of Business Process Outsourcing in India, Journal of Labor Research, 27(3), 291-304.

This is a post-peer-review, pre-copyedit version of an article published in Journal of Labor Research. The final authenticated version is available online at: http://dx.doi.org/10.1007/s12122-006-1026-8.

*** Reprinted with permission. No further reproduction is authorized without written permission from Springer. This version of the document is not the version of record. $* * *$

Abstract:

We identify managerial challenges and opportunities faced by business process outsourcing (BPO) firms in India by interviewing 28 executives in lower $(\mathrm{n}=10)$, middle $(\mathrm{n}=11)$, and upper management $(\mathrm{n}=7)$ in 15 BPO firms. Content analysis of the responses revealed human resources and organization-related challenges as the most critical issues. SWOT (Strengths, Weaknesses, Opportunities, Threats) analysis uncovered future opportunities, e.g., Knowledge Process Outsourcing. Secondary data, from four global research agencies and a national trade association, supported our findings. Organizational changes to address challenges and to exploit opportunities are explored.

Keywords: Business Process Outsourcing | Core Competency | Relational View | Middle Management | Primary Data Analysis

Article:

\section{Introduction}

Grossman and Helpman's (2005: 135) statement, "We live in an age of outsourcing," clearly indicates that outsourcing is now an accepted business strategy. One of the most common forms of outsourcing is business process outsourcing (BPO), i.e., transferring the operational ownership of one or more of the firm's business processes to an external provider that, in turn, manages the processes according to some predefined metrics (Ghosh and Scott, 2005; Stone, 2004).

Organizations are increasingly relying on offshore BPO partners for myriad operations. In some cases, organizations are outsourcing their entire global back-offices, including functions like human resources (HR), to leverage the cost and time advantages (Feeny et al., 2005). BPO is a heterogeneous and rapidly growing offshore market with a projected annual growth rate of 60 percent (Tapper, 2004). Brown and Stone (2004) reported that BPO accounted for 34 percent of the global outsourcing contract value in 2004 and projected that BPO services would grow from $\$ 1.3$ billion in 2002 to $\$ 4.3$ billion in 2007. 
The growing number of global contracts and alliances focusing on BPO service delivery clearly demonstrate the organizations' beliefs in the BPO value-propositions. BPO suppliers not only help reduce clients' costs, but also provide expertise, help improve clients' services, and increase clients' profits. Client and vendor organizations seeking to exploit the benefits of a BPO relationship need to mutually understand their goals, values, and capabilities before entering into an outsourcing partnership (Feeny et al., 2005). The relational view of outsourcing (Dyer and Singh, 1998) also emphasizes shared goals and mutual understanding of processes and decisions between client and vendor for a win-win situation. Thus, for the client, understanding the vendor's end of the BPO market may be a critical factor in their partnership. For example, issues such as HR, technology, and training may directly affect clients' operations. Moreover, clients must be aware of offshore BPO markets to better negotiate contracts, handle competition, make strategic decisions about ownership, and build long-term vendor relationships. For example, some global companies establish their own outsourcing operations at offshore locations called "captive BPO centers," so understanding the challenges and opportunities of the BPO industry in such locations may be immensely valuable.

Prior research on offshore outsourcing has uncovered some broad concerns including infrastructure, cultural differences, accents, language ability, contractual problems, and fear of reduced service levels (Tapper, 2004; Walsham, 2001). Although these studies enhance our understanding of common issues associated with offshore outsourcing, specific issues affecting offshore vendors must be examined and their relative significance assessed. Thus, we focus on the following three points: (1) the unique managerial challenges of vendors in major offshore locations like India; (2) the issues perceived as most critical by the management of vendor operations in these locations; and (3) the opportunities for BPO firms in such locations.

Because India is the world's leading offshore outsourcing destination, studying BPO operations there is crucial. In 2003, India accounted for 75 percent of total BPO offshore delivery value, a value that is expected to increase by 55 percent annually over the next five years (Neale, 2004). India's revenue from BPO operations is expected to grow from approximately $\$ 1$ billion in 2002 to $\$ 13.8$ billion in 2007 , and its share of supply is projected to be 57 percent of the offshore BPO market (Scholl et al., 2003). See Table 1.

Table 1. India's Competitive Position Relative to Other Countrues

\begin{tabular}{|lcccccccccc|}
\hline Country Ratings & India & China & Israel & Africa & $\begin{array}{c}\text { South } \\
\text { Ireland }\end{array}$ & Northern & Czech & & \\
Ireland & Republic & Poland & Hungary & Russia \\
\hline Government Support & E & F & G & F & VG & VG & P & F & F & P \\
Labor Pool & E & G & G & F & G & G & F & G & G & VG \\
Infrastructure & F & P & VG & F & VG & VG & F & F & P & P \\
Education System & VG & F & VG & G & VG & VG & G & G & F & VG \\
Cost & E & E & F & VG & G & F & VG & G & VG & E \\
Political Stability & F & F & P & F & G & E & VG & G & F & F \\
Cultural Compatibility & F & P & VG & E & E & E & VG & VG & VG & G \\
Data/IP Security & G & P & VG & G & E & E & F & F & F & P \\
Overall Climate & VG & P & F & F & G & G & F & F & P & P \\
\hline
\end{tabular}

Note: $\mathrm{P}=$ Poor; $\mathrm{F}=$ Fair; $\mathrm{G}=$ Good; VG Very Good; and $\mathrm{E}=$ Excellent.

Source: Gartner (2004).

Herein, we examine some issues germane to Indian BPO firms. Specifically, we investigate the managerial and operational challenges and the future opportunities available to Indian BPO 
firms. We also explore organizational changes that can be initiated internally to address those challenges and exploit those opportunities. Qualitative research methodology was used, and interview data were collected from executives in 15 firms. Secondary data were also obtained from four global research agencies and a national trade association.

Section II justifies the need for our study. Section III develops the theoretical support from previous outsourcing literature. Section IV presents the data and findings from content analysis. Results and implications are discussed in Section V. The last section presents conclusions and recommendations.

\section{Business Process Outsourcing: Types and Motives}

Business process outsourcing can be defined as the delegation of one or more IT-intensive business processes to an external provider that, in turn, manages the selected processes based on defined and measurable performance metrics (Stone, 2004). IT-based BPO is the fastest growing business globally. Its phenomenal growth can be attributed to technological advancements, such as the Internet and mobile services, which have reduced communication costs and facilitated the internationalization of business processes and services (Mahnke et al., 2005).

The BPO industry is heterogeneous, differentiated by horizontal process domains such as HR, logistics, or finance, and vertical specializations such as medical transcription in the health sector and check processing and imaging in banking. Other categorizations also exist. A distinction can be made between onshore and offshore BPO: Onshore BPO refers to outsourcing to a domestic or nearby vendor whereas offshore refers to the vendor from a different country. For example, for U.S. clients, Canada is considered an onshore location, and India is offshore. Another classification is discrete-process BPO, comprehensive BPO, and a multi-domain BPO (Stone, 2004). Discrete-process BPO refers to a single-process BPO where the vendor is responsible for only one process, for example accounts payable in banking. In a comprehensive BPO, the vendor undertakes multiple business processes within a single support area, such as HR. Multi-domain BPO is more complex: The vendor supports various clients' functions across multiple support groups. For example, a vendor may be responsible for HR, finance, and accounting, as well as customer relations.

The third classification divides BPO on the basis of type of service. It includes: (1) front-office processing, (2) middle-office processing, and (3) back-office processing. Front-office BPO includes customer service and technical support services; middle-office processing includes services such as banking, insurance, telecom, transportation, and utilities; back-office BPO supports functions such as HR and finance and accounting.

The increasing trend of outsourcing has generated considerable debate as to why firms outsource and various explanations have been offered by scholars. Firms may be driven by the need to reduce costs (Quinn, 1992), improve responsiveness to changing market conditions (D'Aveni and Ravenscraft, 1994), concentrate on core activities, or to achieve a combination of these benefits (Kern et al., 2002). Traditionally, outsourcing was a means to lower the costs of production and processes, and even today, economies of scale are cited as a major motivation to outsource (Kakabadse and Kakabadse, 2005). For example, cost-effective access to specialized skills 
(Finlay and King, 1999) and saving on overhead through short-term cost savings (Klein, 1999) have been mentioned as critical reasons for outsourcing. From another perspective, the emergence of globalization has forced firms to concentrate on their core activities to remain competitive, which has led to the notion that firms should identify and outsource their non-core processes (Chalos and Sung, 1998; Currie and Willcocks, 1997). A third perspective is that longterm relationships between clients and BPO vendors can help clients enhance their existing competencies and create new ones (DiRomualdo and Gurbaxani, 1998).

In general, three theoretical approaches have been used to explain why companies make outsourcing decisions: (1) transaction-cost theory, (2) the competence-based view, and (3) the relational view. Figure 1 illustrates the three approaches.

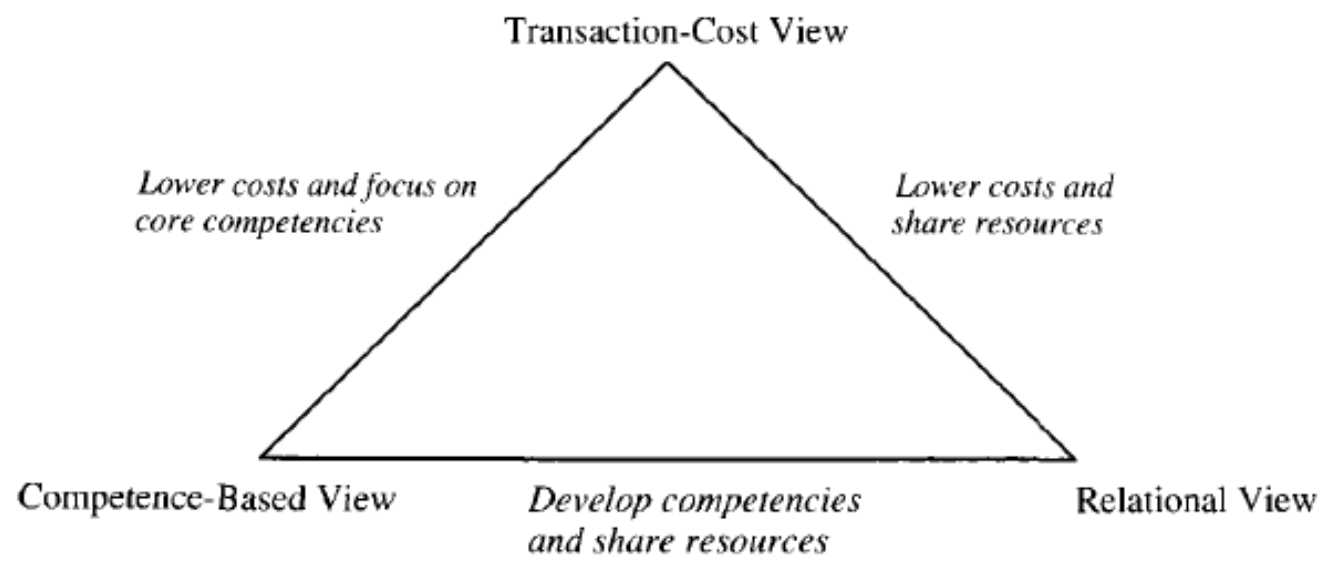

Figure 1. Theoretical Perspectives on Outsourcing

Transaction-Cost View. According to transaction-cost theory, the decision to outsource or internalize is determined by the relative transaction and production costs associated with the process or service (Williamson, 1975). Transactions include three dimensions: frequency of transactions, uncertainty, and degree of asset specificity. A firm will outsource its business processes if all dimensions of transactions are low (Mahnke et al., 2005). This approach advocates that the contracts between the client and vendor must be detailed and specific to avoid opportunism and performance-measuring problems (Lacity and Willcocks, 1998; Poppo and Zenger, 2002). But such formal and highly specific contracts may lead to distrust and opportunism (Ghoshal and Moran, 1996). This view is criticized for its emphasis on overspecification that fosters rigidity and distrust among vendors.

Competence-Based View. The competence perspective is based on the firm's resources and capabilities. According to Barney (1991), a firm's competitive advantage is derived from those capabilities that are unique, inimitable, and non-substitutable. These capabilities constitute the core competencies of the firm (Prahalad and Hamel, 1990). According to the competence approach, a firm may outsource activities other than its core competencies (Quinn and Hilmer, 1994). For example, a firm should outsource its IT activities if IT is not part of its core competencies (Gilley and Rasheed, 2000; Steensma and Corley, 2002). Recently, the focus has shifted to outsourcing to access critical resources needed to improve performance. Firms have started outsourcing even some of their core processes and activities to maintain a competitive edge. Thus, this perspective of outsourcing is considered incomplete. 
Relational View. The inadequacies of the transaction-cost and competence-based views have brought about the relational view that draws from both the transaction-cost and competencebased approaches. This relatively new perspective focuses on creating value through different forms of partnerships. According to Dyer and Singh (1998), "relational rents" are created when partners share, combine, or invest their assets, knowledge, or capabilities, or employ effective governance to lower their transaction costs or improve synergies. Thus, a firm will outsource only if the vendor-client relationship offers relational rents generated through inter-firm exchange or sharing of knowledge, capabilities, and assets. This view may be particularly relevant in case of BPO where the firms may be mutually interdependent, and firms may have to share valuable knowledge with vendors to gain access to their knowledge bases (Mahnke et al., 2005).

Thus, BPO decisions may be driven by any one or a combination of these perspectives. Irrespective of the reasons for outsourcing, BPO is growing rapidly. But the industry is not without its problems and challenges, both for clients and for vendors. Clients are concerned about safety, quality, and finding the right outsourcing partners; vendors must deal with high costs, operational problems, and competition. Though some attempts have been made to examine these issues, research on specific vendors' markets, such as India's BPO industry, is still limited. We explored the Indian BPO industry and uncovered some unique challenges and opportunities.

\section{Data}

Our data were collected from both primary and secondary sources. The primary data came from semi-structured interviews conducted between February and April 2005. Secondary data were also obtained from four global research agencies and an Indian national trade association. The sample consisted of 28 management executives from 15 major Indian BPO organizations. The respondents were selected by the contact person in each organization. Of the 28 executives, ten were drawn from lower management, 11 from middle management, and seven belonged to upper management. The sample was drawn from different levels of management to overcome any response bias due to the manager's status in the organization and to obtain perceptions from all levels of management common to Indian BPO firms. The sample consisted of five females and 23 males with ages ranging from 20 to 43 years, with a mean of 31.6 years. Number of years of work experience in a BPO firm ranged from five months to 7.5 years, with an average of 3.2 years.

The BPO organizations were selected from different parts of the country to minimize any geographical bias. All the organizations were well established and had more than 1,000 employees providing support for different business processes such as technical support, customer services, HR, insurance, banking, and software. A majority had U.S.-based companies as clients.

Using a semi-structured interview format, respondents were asked ten open-ended questions related to positive and negative aspects of working in the BPO industry, managerial challenges, recent changes, and future trends:

1. What are the positive aspects of working in the BPO sector? 
2. What are the negative aspects of working in the BPO sector?

3. What recent changes have you witnessed in your job/organization?

4. What are the major challenges faced by you/your organization?

5. What are the strengths of the Indian BPO industry?

6. What are the weaknesses of the Indian BPO industry?

7. What opportunities exist for the Indian BPO industry?

8. What are the threats to the Indian BPO industry?

9. How has the external environment changed recently?

10. Any other information that you would like to share?

Information was also gathered on company size, business operations, major clients, and respondent's age, gender, work experience, and job designation. The respondents were interviewed by telephone and average time per interview was approximately 50 minutes. After the initial interviews, the authors contacted the respondents again for further clarification and information as required.

Interview responses were then content analyzed. The first stage of content analysis involved unitizing the data. According to Krippendorff (2004), units are wholes that are distinguished and treated as independent elements. Units can be defined on the basis of categorical, thematic, syntactical, physical, and propositional distinctions. In the present study, units were defined on the basis of categorical distinctions, and the primary author unitized the 28 interview transcripts into distinct meaningful elements. These units were independently examined by three researchers who extracted themes and organized the data into meaningful categories. Examples of statements used to characterize themes included the following: "The reason I am staying in the industry is good salary," "you get to work with educated people," "the worst part of the job is the night shifts," and "it is very difficult to stop people from leaving." These examples were used to identify themes related to HR, work environment, and job design. On comparing and discussing the categories, ten broad categories emerged that described the interview data.

In the second phase of analysis, three Ph.D. students ${ }^{1}$ were recruited as independent coders to assign the elements in the identified categories and inter-coder reliability was assessed. Cohen's Kappa (Cohen, 1960) was used to compute the inter-coder reliability, because it is considered most appropriate for classifications of nonquantitative data (Futrell, 1995). Data were also analyzed at other levels. For example, the primary author also segregated the data according to positive and negative statements, the three levels of management, and the managerial functions to analyze issues at the organizational level. To identify the industry-level issues, the SWOT (strengths, weaknesses, opportunities, threats) analysis framework was used.

Secondary data were gathered from four global research agencies that conduct global and country-specific research on the BPO industry (Brown and Stone, 2004; Neale, 2004; Tapper, 2004). A national trade association was also contacted. The primary author obtained membership in these organizations to access the latest research, and data were downloaded from the Internet.

\section{Results and Discussion}

\footnotetext{
${ }^{1}$ We thank Eric Gresch, Steve Brown, and Virajanand Varma for their help with primary data analysis.
} 
The major themes that emerged from the primary content analysis were: career and business prospects, HR issues, motivation and stress, work environment, customer relations, competition, infrastructure and technology, client-vendor relations, change-related issues, and costs and quality (Table 2). The overall Kappa coefficient was .72, a value acceptable for qualitative studies (Futrell, 1995). The Kappa coefficients for different categories ranged from .58 to .85. Based on the frequency with which the elements belonging to each of the themes were mentioned by the respondent, the most important themes were identified. Differences arose at three levels of management on relative importance of the themes, but overall HR, motivation and stress, career and business prospects, and change-related issues were most commonly mentioned. These were the themes that emerged across all management levels. On analyzing the data at multiple levels, various issues specific to each management level and various management functions emerged.

Table 2. Major Themes and Samples of Corresponding Interviewee Statements

\begin{tabular}{|c|c|}
\hline Major Themes & Interviewee's Statements or Examples \\
\hline Career and Business Prospects & $\begin{array}{l}\text { "many career options like trainer, team leader, service delivery manager" } \\
\text { "in just about } 3 \text { years } 1 \text { was able to reach assistant manager level" }\end{array}$ \\
\hline HR Issues & $\begin{array}{l}\text { "it is difficult to stop people from leaving" } \\
\text { "giving feedback, especially negative feedback to employees is a problem, we have } \\
\text { to portray it positively somehow" }\end{array}$ \\
\hline Motivation and Stress & $\begin{array}{l}\text { "sometimes the work pressures are just too much" } \\
\text { "people are frustrated and not satisfied with jobs" }\end{array}$ \\
\hline Work Environment & $\begin{array}{l}\text { "very good, open, and friendly culture" } \\
\text { "the work environment is good" }\end{array}$ \\
\hline Customer Relations & $\begin{array}{l}\text { "there are a bunch of customers who just don't want to talk to an 'Indian,' handling } \\
\text { them is a problem"' } \\
\text { "customer care issues like cultural differences need to be addressed" }\end{array}$ \\
\hline Competition & $\begin{array}{l}\text { "outsourcing might shift to China, Philippines, etc. as cost factors are increasing" } \\
\text { "competition from captive sector." }\end{array}$ \\
\hline Infrastructure and Technology & $\begin{array}{l}\text { "still lots of improvements needed in infrastructure" } \\
\text { "good infrastructure and technology makes India a good destination" }\end{array}$ \\
\hline Client-Vendor Relations & $\begin{array}{l}\text { "meeting client demands is very challenging" } \\
\text { "company went into strategic partnership and merged with client for better salaries, } \\
\text { work culture" }\end{array}$ \\
\hline Change-Related Issues & $\begin{array}{l}\text { "convincing the employees of embracing the constantly changing client policies is } \\
\text { difficult" } \\
\text { "many changes-clients' processes, policies keep on changing rapidly" }\end{array}$ \\
\hline Cost and Quality & $\begin{array}{l}\text { "client implemented quality checks and standards" } \\
\text { "it is turning costly for company as they make much less profits now; pay increases" }\end{array}$ \\
\hline
\end{tabular}

Note: The statements are randomly selected from responses of upper-, middle-, and lower-level managers.

Managerial Challenges. Challenges reported by the managers at the three levels were different (Table 3). The major challenges pertained to job or HR issues at the lower management levels; HR and directing at the middle management level; and planning, directing, and controlling at the upper management level. For example, at the lower management level, the major challenges included meeting targets, dealing with customers, and maintaining work-life balance. At the middle management level the major challenges were to motivate employees and handle attrition and absenteeism. At the upper management level, client demands, motivation, competition, and costs were challenges. Organizations need to identify challenges and provide relevant information, support, and training to personnel to deal with them. 
Table 3. Key Managerial Issues at Lower-, Middle-, and Upper-Management Levels of Indian BPO Firms

\begin{tabular}{|c|c|c|c|}
\hline & Lower Management & Middle Management & Upper Management \\
\hline Positive Aspects & $\begin{array}{l}\text { Work Environment } \\
\text { Growth Prospects } \\
\text { Money } \\
\text { Learning Opportunities } \\
\text { Benefits }\end{array}$ & $\begin{array}{l}\text { Learning/Exposure } \\
\text { Skill Development } \\
\text { Money } \\
\text { Fast Growth } \\
\text { Career Prospects }\end{array}$ & $\begin{array}{l}\text { New Business Areas } \\
\text { Growth Prospects } \\
\text { Manpower Availability } \\
\text { Client Partnerships } \\
\text { IT-based services }\end{array}$ \\
\hline Negative Aspects & $\begin{array}{l}\text { Night Shifts } \\
\text { Tiring/Boring Job } \\
\text { Stress/Lack of Motivation } \\
\text { Bad HR Policies } \\
\text { Attrition }\end{array}$ & $\begin{array}{l}\text { Motivation } \\
\text { Night Shifts } \\
\text { Attrition } \\
\text { Stress } \\
\text { Daily Targets }\end{array}$ & $\begin{array}{l}\text { Tough Job Requirements } \\
\text { HR Issues } \\
\text { Competition } \\
\text { Increasing Cost } \\
\text { Client Requirements }\end{array}$ \\
\hline Recent Changes & $\begin{array}{l}\text { Policies } \\
\text { Technology } \\
\text { Infrastructure } \\
\text { Training } \\
\text { Career Options } \\
\text { Quality Focus }\end{array}$ & $\begin{array}{l}\text { Infrastructure } \\
\text { Technology } \\
\text { Quality Focus } \\
\text { Attitude towards Job } \\
\text { Better Training } \\
\text { Client Policies }\end{array}$ & $\begin{array}{l}\text { Mergers \& Acquisitions } \\
\text { Quality Focus } \\
\text { New Specialized Areas } \\
\text { Experts Joining the Field } \\
\text { Demand for Manpower }\end{array}$ \\
\hline Challenges & $\begin{array}{l}\text { Adapt to Change } \\
\text { Customer Handling } \\
\text { Targets } \\
\text { Shifts \& Health } \\
\text { Competition }\end{array}$ & $\begin{array}{l}\text { Motivation } \\
\text { Attrition } \\
\text { HR Issues } \\
\text { Targets } \\
\text { Client Satisfaction } \\
\text { Employee Satisfaction }\end{array}$ & $\begin{array}{l}\text { HR Issues } \\
\text { Negotiate with Client } \\
\text { Competition } \\
\text { Operational Costs } \\
\text { Client Standards }\end{array}$ \\
\hline
\end{tabular}

Note: The key issues are derived on the basis of frequency of managers' responses, i.e., how often the managers cited these issues during the interview.

Table 4. Major Strengths, Weaknesses, Opportunities. And Threats of Indian BPO Firms

\begin{tabular}{|l|l|l|}
\hline SWOT Category & Percentage of Total Responses & Major Issues \\
\hline Strength & 45.6 & $\begin{array}{l}\text { Human Resource } \\
\text { Cost Advantage } \\
\text { Time Advantage } \\
\text { Work Culture }\end{array}$ \\
\hline Weaknesses & 51.9 & $\begin{array}{l}\text { Job Requirements } \\
\text { HR Issues } \\
\text { Operational Issues } \\
\text { Cultural Gap }\end{array}$ \\
\hline Opportunities & 54.4 & $\begin{array}{l}\text { Growth Related } \\
\text { HR Related } \\
\text { IT Based Services } \\
\text { Client Partnerships }\end{array}$ \\
\hline Threats & $\begin{array}{l}\text { Competition } \\
\text { Unpredictability } \\
\text { Increasing Costs } \\
\text { Client Demands }\end{array}$ \\
\hline
\end{tabular}

Notes: The Strengths, Weaknesses, Opportunities, and Threats (SWOT) framework was used to analyze BPO firms' internal and external environment. The percentages are non-additive. The key issues in each SWOT category are derived on the basis of frequency with which the issues were mentioned by the interviewees.

Opportunities and Threats. In general, perceptions about opportunities exceeded threats, so most managers had a positive outlook regarding the future of the BPO industry (Table 4). The major 
opportunities mentioned by managers included high growth potential, new business processes, and new client partnerships. For example, European clients are now also outsourcing high-end processes. Moreover, clients are now looking for long-term, stable relationships, and BPO is moving towards a relational model. New business areas such as publishing, research and development, market research, and knowledge process outsourcing (KPO) are emerging. Firms must identify these opportunities and strategize accordingly for long-term sustainability. Major threats included competition from other countries like China and from the captive centers set up by foreign companies to support their outsourcing operations.

Most of the responses related to change reflect more future opportunities ( 67 percent), as opposed to threats (13.9 percent); and strengths (20 percent) as compared to weaknesses ( 0 percent), so the industry is improving over time. But BPO firms need to continue their efforts to make their offerings unique and value-added for the client.

Perceptions of the BPO Industry at Different Management Levels. Though the percentage of total positive and negative responses was almost the same, negative responses were slightly higher for lower and middle management; thus, although employees are attracted to the industry because of various advantages firms offer, many issues still need attention. Organizations must identify and solve these issues to improve job attractiveness and retain employees.

Negative responses dominated the positive responses of lower and middle managers, but positive responses exceeded negative ones for upper managers. The perceptions of top management may differ from those of middle and lower managers, and top managers are either unaware of the critical issues in their organizations or do not consider them important. In order to compete in the long run and retain star performers, firms must conduct a thorough diagnosis to uncover critical issues through employee participation and address them.

As employees gain experience and move to higher management levels, they likely get adjusted and perceive fewer problems. Thus, the organizations should make efforts to retain employees and develop a career path to deal with attrition. There is a need to reconsider the hiring and firing policies, and focus on employee development and retention tactics.

Managerial Functions Needing Attention. The managerial functions of organizing, staffing, and directing emerged as most important across all levels (Table 5). The majority of responses were related to these three managerial functions, with the exception of change-related responses, where planning, and not directing, emerged as important. At lower management levels, most issues were HR and job related. Though HR got the highest percentage of positive responses, it is also the biggest concern. Major HR-related issues included attrition, HR policies, absenteeism, performance appraisal, and manpower allocation. In organizing, the major concerns at the lower management level were related to job design and job requirements, like night shifts, monotony, and long hours. Organizations need to reframe their HR-related policies, and revamp their compensation and appraisal systems. Job redesigning is needed to make work more meaningful and satisfying. 
Table 5. Percentage of Positive, Negative, Change-Related, and Challenge-Related Responses for Various Managerial Functions

\begin{tabular}{|lcccc|}
\hline Management Functions & $\begin{array}{c}\text { Percentage of } \\
\text { Positive Responses }\end{array}$ & $\begin{array}{c}\text { Percentage of } \\
\text { Negative Responses }\end{array}$ & $\begin{array}{c}\text { Percentage of Change- Percentage of Challenge- } \\
\text { Related Responses }\end{array}$ & $\begin{array}{c}\text { Pelated Responses } \\
\text { Related }\end{array}$ \\
\hline Planning & 0 & 8.1 & 25.9 & 7.2 \\
Organizing & 19.8 & 36.1 & 22.8 & 20.0 \\
Staffing/HR & 72.8 & 44.2 & 27.8 & 30.8 \\
Directing & 2.5 & 11.3 & 0 & 16.1 \\
Controlling and Budgeting & 0 & 5.0 & 10.1 & 11.7 \\
\hline
\end{tabular}

Notes: Gulick's (Gulick and Urwick, 1937) POSDCORB model was used to analyze the data according to managerial functions. The percentages are non-additive.

At the middle-management level, critical issues were related to HR, organizing, and motivation. Middle-level managers have difficulty retaining good employees, motivating them to put in their best effort, and keeping them happy. Often managers are not trained to work with teams, and directing and motivating numerous teams simultaneously is challenging. Organizations must find ways to intrinsically motivate their employees to improve effectiveness. Managers at all levels must be trained to lead teams and address team-related issues. By developing a culture where self-managed teams can thrive, organizations can overcome many of the motivational and team issues.

Changes were reported usually in the areas of HR, organizing, planning, and business prospects-areas that managers identified as critical. Though the industry is supposedly moving in the right direction by undergoing changes in these areas, constant change may cause negative employee responses because adjusting to constant change is disruptive; alternatively, firms may not be dealing with the right issues. Organizations need to conduct in-depth analyses to uncover relevant issues unique to their own context and then implement suggested changes.

Secondary Data Analysis. Generally, the findings from the primary data analysis are supported by the secondary data. Primary data pointed to growth prospects, fast growth, and more opportunities than threats, like data from Gartner Research, but competition as a possible threat is ruled out: According to trends from research agency data, India will remain competitive. The BPO market will grow to $\$ 173$ billion by 2007 , and India will account for a major portion of the offshore outsource activities. Forty percent of the Fortune 500 firms were estimated to have outsourced offshore by the end of 2004. The offshore outsourcing market will grow to $\$ 160$ billion in 2005, up from $\$ 101$ billion in 2000. India will remain the dominant offshore service provider through 2008, with no other nation achieving a double-digit share of the global offshore service revenue.

The primary data analysis revealed a trend towards new specialized business processes such as $\mathrm{R} \& \mathrm{D}$, publishing, and KPO, which is supported by secondary data. Also, IT-based services emerged as an opportunity in both primary and secondary analysis. The trend is for higher value, more complex processes to be located offshore (Brown and Stone, 2004). "High-value" BPO, such as accounting, paralegal, medical, research, and banking, will continue to thrive. The highvalue BPO market did not exist in 1998; by 2010 it is predicted to be a $\$ 50$ billion per year market. Software continues to be off-shored. 
Primary data analysis uncovered some other issues such as attrition, performance appraisal, skill development, policy changes, cultural gap, increasing costs, and organizing issues. These are also reflected in the secondary data analysis. As companies scale-up their offshore operations, the need for (1) higher cross-cultural communications, (2) sophisticated program-management skills, and (3) knowledge-transfer skills will occur. Vendor focus will shift from business process aspects such as skills and costs, to more domain knowledge, transition challenges, change management, HR issues, and governance.

Increased competition, both locally and from global vendors, will continue to chip away at the margins of domestic vendors, particularly in the more developed offshore markets. Pricing pressure will continue. Vendors that demonstrate strong client relationships, deep domain knowledge, and productivity improvements will be able to better protect their margins.

\section{Recommendations}

BPO vendors must take action at both strategic and operational levels. At the strategic level, they need to rethink their business goals, revamp their organizational structures, and improve clientvendor relations. At the operational level, action plans are needed to deal with issues like employee motivation, attrition, and training and development. Based on our primary and the secondary data ${ }^{2}$ we conclude with recommendations for BPO vendors.

Identify your strengths, core competencies, and key business processes and build on them. The vendors need to identify their strengths and what processes contribute to core competencies. The future of vendor firms will depend on value-added services that they provide to clients through their unique resources. With competition intensifying, only firms that develop long-term client relationships by offering unique inimitable capabilities will survive.

Understand clearly the goals and critical success factors before entering a BPO contract. The clients, as well as the vendors, should be clear about their business goals. For example, the vendor should be told whether to focus on a long-term relationship or short-term profits. The contract between client and vendor should clearly indicate future goals, expectations, performance criteria, etc.

Develop a thorough understanding of the BPO industry; create an effective management information system. Knowledge can be the competitive edge for the vendors who are able to develop and sustain an effective management information system to keep them abreast of the changes occurring, such as new technologies, changing client requirements, government regulations, and customer attitudes.

Prepare for a long-term, value-based relationship with the client, and identify resources to be shared. Vendors must recognize that outsourcing is about partnership and not just about providing a service or solution. In order to establish a long-term and mutually beneficial client

\footnotetext{
2 The recommendations are based on primary data and secondary data obtained mainly from Gartner Research (Scholl and Stone, 2001) and NASSCOM, downloaded from their websites $<$ www.bpo.nasscom.org $>$ and $<$ www.gartner.com $>$, respectively. Many of tile recommendations made by these agencies in their reports on Indian BPO industry corresponded with the primary data analysis in the present study.
} 
relationship, vendors must show their commitment through investing in resources and sharing them with the client.

Establish realistic performance standards and an active appraisal system. A thorough control and appraisal process should be in place. Vendors should benchmark their processes not only to constantly improve their operations, but also to satisfy trust and quality issues commonly raised by the clients.

Develop clear communication networks at all levels of management. Clear and transparent communication of the goals, policies, and plans of the company at all levels is crucial to success. Employee participation in planning and decision making and in articulating new policies may be an important tool to improve employee motivation.

Reframe HR policies; rethink job designs to make them more meaningful. In spite of the growing awareness that $\mathrm{HR}$ is the major vendor issue, little has been done other than raising salaries. But our findings suggest that merely improving salaries and benefits will not solve the severe problems of attrition and motivation. Changes must be made at the policy level, and vendors may have to re-think issues like job security and selection procedures to address HR problems. For example, vendors may have to reconsider the hiring and firing policies and focus on employee development and retention tactics.

Find ways to intrinsically motivate employees to improve effectiveness. Because motivation is one of the biggest challenges at the middle-management level, vendors must find creative ways to motivate employees. For example, developing a team culture, rotating employees through various jobs, defining a career path, and stabilizing employment are potential options.

Conduct a thorough diagnosis to uncover critical issues through employee participation and take steps to deal with them. Vendors must realize that each of them have unique cultures, resources, capabilities, weaknesses, and strengths. They have to discover their uniqueness by undertaking organizational diagnoses and uncover issues specific to their organization and tailor their action plans accordingly.

Create management processes that facilitate change and its implementation. One of the critical success factors for vendors will be the ability to adapt to change and foster a learning culture. Because outsourcing is a highly dynamic field, employees must be open to change. Managers must develop change management skills. Organizations need to develop a culture of continuous learning.

\section{References}

Barney, Jay. "Firm Resources and Sustained Competitive Advantage." Journal of Management 17 (March 1991): 99-120.

Brown, Robert and Lisa Stone. "Business Impact of the BPO Market in 2005." Research Note (December 2004): Gartner Research, Document G00123781. 
Chalos, Peter and Jaeyoung Sung. "Outsourcing Decision and Managerial Incentives." Decision Science 29 (Fall 1998): 901-19.

Cohen, Jacob. "A Coefficient of Agreement for Nominal Scales." Educational and Psychological Measurement 20 (Winter 1960): 37-46.

Currie, Wendy L. and Leslie P. Willcocks. "New Strategies in IT Outsourcing: Major Trends and Global Best Practices-Report.” London: Business Intelligence Ltd., December 1997.

D'Aveni, Richard and David J. Ravenscraft. "Economics of Integration versus Bureaucracy Costs: Does Vertical Integration Improve Performance?" Academy of Management Journal 37 (October 1994): 1167-206.

DiRomualdo, Anthony and Vijay Gurbaxani. "Strategic Intent for IT Outsourcing." Sloan Management Review 39 (Summer 1998): 67-80.

Dyer, Jeffrey H. and Harbir Singh. "The Relational View: Cooperative Strategy and Sources of Interorganizational Competitive Advantage." Academy of Management Review 23 (October 1998): 660-79.

Feeny, David, Mary Lacity, and Leslie P. Willcocks. "Taking the Measure of Outsourcing Providers." Sloan Management Review 46 (Spring 2005): 41-48.

Finlay, Paul N. and Ruth M. King. "IT Outsourcing: A Research Framework." International Journal of Technology Management 17 (No. 1/2 1999): 109-28.

Futrell, David. "When Quality Is a Matter of Taste, Use Reliability Indexes." Quality Progress 28 (May 1995): 81-86.

Ghosh, Biswadip and Judy E. Scott. "Interorganizational Knowledge Management in a BPO.” Omaha, The 11th Americas Conference on Information Systems (August 2005).

Ghoshal, Sumantra and Peter Moran. "Bad for Practice: A Critique of the Transaction Cost Theory." Academy of Management Review 21 (January 1996): 13-47.

Gilley, Matthew K. and Abdul Rasheed. "Making More by Doing Less: An Analysis of Outsourcing and Its Effects on Firm Performance." Journal of Management 26 (Issue 4 2000): 763-90.

Grossman, Gene M. and Elhanan Helpman. "Outsourcing in a Global Economy." Review of Economic Studies 72 (January 2005): 135-59.

Gulick, Luther H. and Lyndall F. Urwick, eds. Papers on the Science of Administration. New York: Institute of Public Administration, 1937. Kakabadse, Andrew and Nada Kakabadse. "Outsourcing: Current and Future Trends." Thunderbird International Business Review 47 (March-April 2005): 183-204.

Kern, Thomas, Leslie P. Willcocks, and Eric Von Heck. "The Winner's Curse in IT Outsourcing: Strategies for Avoiding Relational Trauma." California Management Review 44 (Winter 2002): 47-69.

Klein, Paula. "Outsourcing Third Wave." Information Week 761 (November 1999): 126-27. 
Krippendorff, Klaus. Content Analysis: An Introduction to Its Methodology. Beverly Hills, CA: Sage, 2004.

Lacity, Mary C. and Leslie P. Willcocks. "An Empirical Investigation of Information Technology Sourcing Practices: Lessons from Experience." MIS Quarterly 22 (September 1998): 363-408.

Mahnke, Volker, Mikkel L. Overby, and Jon Vang. "Strategic Outsourcing of IT Services: Theoretical Stocktaking and Empirical Challenges." Industry and Innovation 12 (June 2005): 205-53.

National Association of Software and Service Companies. Building Middle Management Expertise for Sustaining Quality Performance. India: NASSSCOM, 2004.

_. India's Value Proposition. India: NASSSCOM, 2004 www.bpo.nasscom.org.

—. Indian ITES-BPO Industry: NASSCOM Analysis. India: NASSCOM, 2004 www.nasscom.org.

Neale, Helen. "Offshore BPO Delivery." NelsonHall BPO and Outsourcing Subscription Service: NelsonHall, 2004 www.nelson-hall.com.

Poppo, Laura and Todd Zenger. "Do Formal Contracts and Relational Governance Function as Substitutes or Complements?" Strategic Management Journal 23 (August 2002): 707-25.

Prahalad, C.K. and Gary Hamel. "The Core Competencies of the Corporation." Harvard Business Review 68 (May-June 1990): 79-91.

Quinn, James B. “The Intelligent Enterprise: A New Paradigm.” Academy of Management Executive 6 (November 1992): 48-63. and Frederick G. Hilmer. "Strategic Outsourcing." Sloan Management Review 35 (Summer 1994): 43-55.

Scholl, Rebecca and Lisa Stone. "Business Process Outsourcing Issues and Options." Research Report: Gartner Research, 2001 www.ganner.com.

Scholl, Rebecca, Sujoy Chohan, Debashish Sinha, and Ravi Datar. "India Will Generate \$13 Billion from Offshore Exports in 2007." Gartner Dataquest (June 2003): Gartner Research, Document ITOU-W-R-115

Steensma, H. Kevin and Kevin G. Corley. "Organizational Context as a Moderator of Theories on Firm Boundaries for Technology Sourcing." Academy of Management Journal 44 (April 2002): 271-91.

Stone, Lisa. "New BPO Definitions Clarify Service Offerings." Research Note (October 2004): Gartner Research, Document G00123758 www.gartner.com.

Tapper, David. "Worldwide and U.S. IT Outsourcing Services 2004-2008 Forecast: A Potential Perfect Storm.” Market Analysis (April 2004): IDC, Document 31089 www.idc.com.

Walsham, Geoff. Making a World of a Difference. Chichester: Wiley, 2001. 
Williamson, Oliver E. Markets and Hierarchies: Analysis and Antitrust Implications. New York: Free Press, 1975. 